\title{
Phage Eco-Locator: a web tool for visualization and analysis of phage genomes in metagenomic data sets
}

\author{
Ramy K Aziz ${ }^{1,2^{*}}$, Bhakti Dwivedi ${ }^{3}$, Mya Breitbart ${ }^{3}$, Robert A Edwards ${ }^{1,4}$ \\ From 10 ${ }^{\text {th }}$ Annual UT-ORNL-KBRIN Bioinformatics Summit 2011 \\ Memphis, TN, USA. 1-3 April 2011
}

\section{Background}

Bacteriophages, viruses that infect bacteria, are the most abundant biological entities on our planet, and their nucleic acids constitute a substantial proportion of total DNA in Earth's ecosystems [1,2]. While the advent of metagenomic methods has allowed the rapid and efficient investigation of microbial and viral communities [3-5], there has not been a comprehensive comparative analysis of phage genes and genomes present in all sequenced ecosystems [6,7]. To examine the abundance and distribution of phage genes in environmental metagenomic sequences, we developed a web-based tool, Phage Eco-Locator [http://www.phantome.org/eco-locator] that screens all publicly available sequenced metagenomes for a user-defined phage genome, or all phage genomes within a user-selected metagenomic sample.

\section{Materials and methods}

The tool relies on pre-calculated tBLASTX searches in which metagenomic sequence reads are the input query and all phage genomes are the BLAST database [8]. For optimization, several BLAST parameters have been tested, and the best results are obtained when all tBLASTX matches above a threshold E-value of $10^{-5}$ are included as positive hits. Positive hits are then mapped to phage genome scaffolds and visualized in two different types of plots: one representing sequence hits at different similarity scores (Fig. 1; upper panel) and another representing the coverage density over phage nucleotides (Fig. 1; lower panel).

\footnotetext{
*Correspondence: ramy.aziz@salmonella.org

1 Department of Computer Science, San Diego State University, San Diego,

CA, 92182, USA

Full list of author information is available at the end of the article
}

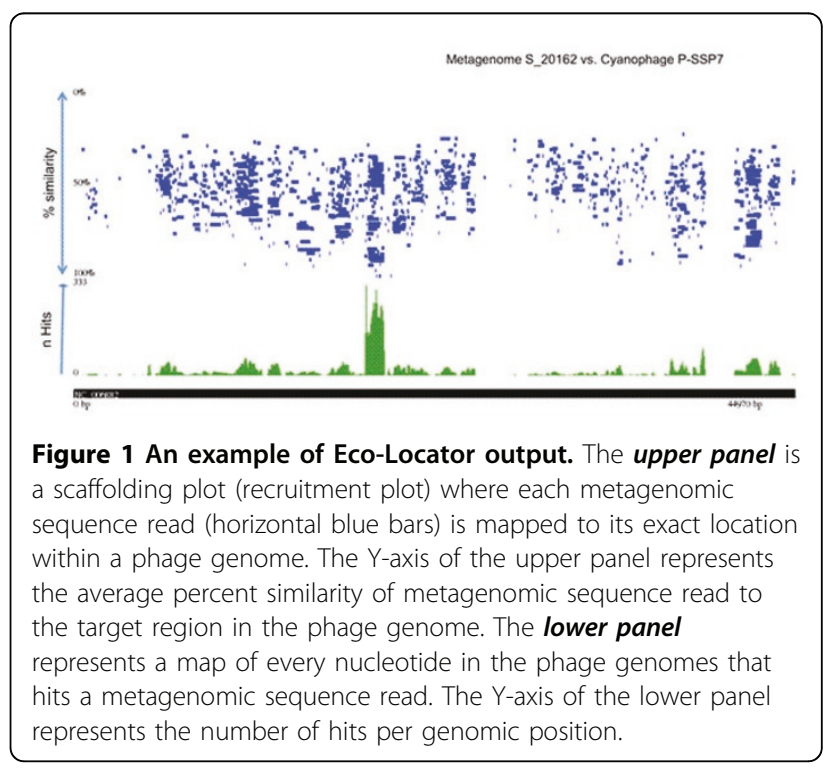

\section{Results}

All 588 phage genomes available in the PhAnToMe database [http://www.phantome.org] (as of January 1, 2011) were screened against 296 de-replicated metagenomic libraries. The graphical output was translated into metrics representing phage abundance, extent and breadth of distribution, and coverage density and evenness. Applying these metrics to all samples demonstrated a pervasive, yet uneven, distribution of phage genes in metagenomic libraries and allowed the separation of phage genomes into distinct groups. The analyses also showed a tendency for phage genomes to prevail in environments similar to their original isolation source, where their bacterial hosts are expected to thrive (e.g., cyanophages in aquatic samples and halophages in hypersaline environments). 


\section{Conclusion}

Phage Eco-Locator effectively allows the global analysis of all phage sequences in metagenomes while also permitting gene-level analysis of individual phage genomes. In the future, application of this tool to sequences from a wide range of ecosystems will enhance our understanding of the factors controlling phage biogeography and environmental selection.

\section{Acknowledgments}

This work was supported by the PhAnToMe grant from the NSF Division of Biological Infrastructure to RAE (NSF DBI-0850356) and MB (NSF DBI0850206).

\section{Author details}

${ }^{1}$ Department of Computer Science, San Diego State University, San Diego,

CA, 92182, USA. 'Department of Microbiology and Immunology, Faculty of Pharmacy, Cairo University, Cairo, Egypt. ${ }^{3}$ College of Marine Science, University of South Florida, St. Petersburg, FL, USA. ${ }^{4}$ Mathematics and

Computer Science Division, Argonne National Laboratory, Argonne, IL, USA.

Published: 5 August 2011

\section{References}

1. Bergh O, Børsheim KY, Bratbak G, Heldal M: High abundance of viruses found in aquatic environments. Nature 1989, 340:467-468.

2. Jiang SC, Paul JH: Gene transfer by transduction in the marine environment. Appl Environ Microbiol 1998, 64:2780-2787.

3. Handelsman J: Metagenomics: application of genomics to uncultured microorganisms. Microbiol Mol Biol Rev 2004, 68:669-685.

4. Casas V, Rohwer F: Phage metagenomics. Methods Enzymol 2007, 421:259-268

5. Schoenfeld T, Liles M, Wommack KE, Polson SW, Godiska R, Mead D: Functional viral metagenomics and the next generation of molecular tools. Trends Microbiol 2010, 18:20-29.

6. Edwards RA, Rohwer F: Viral metagenomics. Nat Rev Microbiol 2005, 3:504-510.

7. Breitbart M, Rohwer F: Here a virus, there a virus, everywhere the same virus? Trends Microbiol 2005, 13:278-284.

8. Altschul SF, Madden TL, Schaffer AA, Zhang J, Zhang Z, Miller W, Lipman DJ: Gapped BLAST and PSI-BLAST: a new generation of protein database search programs. Nucleic Acids Res 1997, 25:3389-3402.

doi:10.1186/1471-2105-12-S7-A9

Cite this article as: Aziz et al:: Phage Eco-Locator: a web tool for visualization and analysis of phage genomes in metagenomic data sets. BMC Bioinformatics 2011 12(Suppl 7):A9.

\section{Submit your next manuscript to BioMed Central and take full advantage of:}

- Convenient online submission

- Thorough peer review

- No space constraints or color figure charges

- Immediate publication on acceptance

- Inclusion in PubMed, CAS, Scopus and Google Scholar

- Research which is freely available for redistribution

Submit your manuscript at www.biomedcentral.com/submit
C Biomed Central 